\title{
PROFESSOR RAUL RODRIGUES GOMES
}

Por ocasião de homenagem prestada ao Professor Raul Rodrigues Gomes, catedrático de Economia Política, em razão de sua aposentação naquela cátedra, por ter alcançado limite constitucional de idade, o Professor José Nicolau dos Santos, catedrático de Teoria Geral do Estado, proferiu a seguinte saudação:

"Feliz e oportuna esta iniciativa da douta Congregação da Faculdade de Direito da Universidade do Paraná, abrigando em seu Nobre Salão professôres e alunos, irmanados todos nêste sentimento comum e unísono de prestar homenagem a um professor que se jubila. Ao receber de meus eminentes colegas o cometimento alto de saudar o Professor Raul Rodrigues Gomes no ato de sua ascenção ao recesso tranquilo e merecido de seu lar, que Cícero defendia como o ideal romano daquêles que já cumpriram, com inteligência e galhardia, os mais afanosos deveres para com a Pátria - otium cum dignitate - ao receber tal cometimento, dizia, não sei bem se me alegro ou me entristeço, - se me conduz na trilha dêste panegírico a mágua ou a exultação.

Creio, senhores, que privo simultâneamente destas duas emoções psíquicas contraditórias e parado- xais. Creio, nobres colegas de Congregação e distintos jovens universitários, que privamos todos, indistintamente, dêste tumulto impreciso das mesmas emoções.

Merece Raul Gomes, como ninguém mais o prêmio administrativo de uma aposentadoria serena e digna, direito que lhe confere muitos anos de luta e labor profíquo, especialmente dedicado à cátedra que lustrou com inteligência e amor. Nós, os seus amigos e admiradores, nos alegramos por isso. Quando, porém, num abraço de despedida - de compulsória e inapelável despedida - assistimos o mestre sábio e compreensivo descer silencioso e constrangido os degraus dessa mesma cátedra, que êle amava e regia com entusiasmo ímpar, nós, todos os seus admiradores e amigos, não poderíamos deixar de macular os olhos com uma aragem de tristeza e desencanto.

Incidiu em cego êrro a douta Congregação da Faculdade de Direito em fazer-me o seu intérprete nesta solenidade. Raul Gomes pela sua vida inquieta e prodigiosa, pela sua inteligência arguta e lesta, pelas suas atitudes virís e tempestuosas, pelo seu caráter ri- 
jo e másculo, pelo seu temperamento bravo e audaz, não exigia nêste instante um simples discursador acadêmico, mas requeria na tribuna a presença de um biógrafo, alguém que com "maior engenho e arte" camoneana pudesse gizar-lhe o magnífico perfil intelectual e moral.

Quando busco uma síntese para definir com um só traço o retrato psicológico de Raul Gomes, lembro-me ainda de uma lição de História e de Direito, que o ilustre mestre teve oportunidade de me ensinar, em um daquêles colóquios longos que sempre mantivemos em esquinas tumultuantes da cidade, alheios ao ruído urbano, ao vaivem ininterrupto do trânsito, à berrante alacridade das vias públicas. Sim. Raul Gomes sempre teve êsse dom invulgar de prelecionar com prazer e austeridade no recinto solene da Universidade, e com o mesmo prazer, displicência e simpatia, sob a fronde de uma árvore, em qualquer banco de jardim ou em qualquer ângulo de praça. Nasceu professor e se sabia fazer professor em tôdas as horas do dia, sem exceção de um só minuto.

Talvez não se recorde o mestre, honrosamente jubilado, que certa vez eu o ouvia discorrer, exata e minuciosamente sôbre a vida de Rui. Dizia-me em conclusão: Aquilo que me comove, aquilo que mais exalto na personalidade inegualável dêsse gênio pátrio, não é o jurisconsulto sábio que foi Rui, nem o poliglota, nem o político, nem o administrador, nem o literato puríssimo e dominador absoluto da nossa língua, nem o republicano histórico. O que mais admiro em Rui foi ter sido êle, como ninguém o igualou, "um professor da energia".

Num só traço psicológico, eis aqui, também, a personalidade definida de Raul Gomes. Como o grande Rui, Raul Gomes soube ser também "um mestre da energia".

Acompanhando sempre, ou mais de longe ou de mais perto, os gestos, as atitudes, os ideais de Raul Gomes, jamais deixei de admirarlhe a bravura com que se dispunha a pelejar um bom combate. Vocação inata de gladiador, nunca o encontrei receioso de enfrentar a luta, os prélios intelectuais, as campanhas polítitcas, as polêmicas de imprensa em que se empenhou sempre, sem descanso, sem armistícios breves, sem armas ensarrilhadas. Se há uma figura humana que possa representar com veracidade o "Homo Ludens" do filósofo alemão Huizinga, ela se desenha sem dúvida em Raul Gomes: é êle o competidor, o atleta, o lutador permanente, alerta, disposto a jogar qualquer parada, a qualquer momento e em qualquer lugar, animado por uma irresistível sedução lúdica da vida.

Incansável, infatigável, persistente, nós o assistimos laurear-se como Bacharel em Direito já avançado em anos, já escritor de nomeada e professor emérito do Instituto de Educação. A meia altura da vida, os diplomas representam apenas lauréis acadêmicos, ampliação louvável mas desinteressada da cultura, sem objetivos imediatos ou aspirações mediatas. Não, porém, para um homem que se chama Raul Gomes, "um mestre da energia".

De posse de um título de Bacharel, logo pensa Raul Gomes em 
acrescentar-lhe o título de Doutor em Direito e o Diploma de Docente Livre daquela mesma Faculdade onde, há poucos anos, assentavase em bancos discentes. Em 1946, com a tese "A Economia Mundial e o Descobrimento do Caminho Marítimo das Indias", inscreveu-se a concurso, que realiza com brilho no ano seguinte. Seu ideal lúdico, seu espírito de gladiador, não estava, contudo, superado.

Assumindo, como Docente Livre a Cátedra interina de Economia Política, professando agora o magistério superior, com ânimo e entusiasmo - por que não dizer melhor - com verdadeira exaltação, vê Raul Gomes - acrescido fìsicamente de mais anos, mas psìquicamente jovem, remoçado sempre, milagrosamente rejuvenecido ser colocada em disputa pública essa mesma Cátedra, que ainda não lhe pertencia formalmente. Não seria êle, por certo, quem desdenhasse novo concurso, novo certame intelectual, cuja oportunidade se abria. Em 1949, defendendo a tese "Caminhos da Paz - Maior produção e melhor distribuição", fez-se, com louvor e mérito, Professor Catedrático de Economia Política.

Quando afirmo que Raul Gomes jamais rejeitou a luta, minto. Lembro-me que anos já ressoados, anos que já dormem no arquivo das minhas recordações e saudades, sentamos ambos em uma mesma banca de concurso, êle como examinador exímio, eu, pobre de mim, como examinando bisonho, jogando a sorte, sem recurso, de uma temeridade: o desejo de me alçar a esta Cátedra e ao convívio desta egrégia Congregação. Incidentemente, impensadamente eu abor- dara, na tese de candidato, uma soma de problemas econômicos internacionais. Raul Gomes poderia ter pulverizado o examinando, como mestre insígne de Economia e de Direito. Contudo, seu espírito lúdico falou mais alto. O competidor, para o debate oral, era mais fraco do que êle, além disso já estava exausto ante a dialética impiedosa de outros examinadores precedentes.

Confesso, senhores professôres, que foi agradável para mim, mas não foi absolutamente surprêsa para quem conhece de perto a alma e o coração de Raul Gomes, vê-lo cobrir de elogios benevolentes o candidato tímido, e, com o ímpeto e a agilidade de um mosqueteiros de Dumas, sacar de seu florete mágico para tomar a defesa de seu antagonista formal, contra seus próprios companheiros de banca. "A Justiça deve pender sempre para o lado mais fraco", escrevera Rui. Raul era um leitor assíduo de Rui.

Falei em mosqueteiro propositalmente. Pedro Calmon, em uma de suas memoráveis orações à mocidade paranaense, nêste mesmo recinto, em horas que já vibraram, dizia-lhe que se um livro, um só livro, tivesse de recomendar aos jovens de hoje, êsse livro seria "Os três mosqueteiros", leitura que se nos parece inconsequente, mas capaz de transmitir à alma juvenil a fôrça e a beleza de um ideal humano, a fidalguia das atitudes desinteressadas, a fé romântica nas cousas belas da vida.

Tenho a convicção de que Raul Gomes jamais leu as bravatas dos mosqueteiros de Dumas. É êle o próprio D'Artagnan redivivo. Alma 
de gascão, sentimental e bravo, se quizermos ter a certeza de que lado pende a justiça de uma causa, nos árduos problemas que afligem 0 mundo moderno, não deixemos de olhar primeiro o lado em que se posta êsse grande mestre da mocidade paranaense.

Senhores, seria imperdoável que eu me alongasse mais. A biografia de Raul Gomes não pode ser breve. Deixo-a num modesto esbôço de uma introdução. Não falarei dêle como jornalista, essa outra Cátedra que êle enobrece, porque o jornalista é um professor de multidões.

Saúdo-o, em nome desta Congregação, por haver merecido justa e honrosa jubilação magisterial. Estas salas continuarão a guardar o éco estrepitoso das palmas e dos aplausos estudantís, que costumeiramente encerravam as suas aulas e os seus debates acadêmicos. Evito, porém, de repetir aqui o lema aureo de Cícero - otium cum dignitate - porque o eminente homenageado não se sente grato pelo prêmio constitucional que se lhe impõe. Lí, de fato, com admiração e reverência, mas sem surprêsa alguma, no Livro de Presença dos Professôres, esta observação breve e eloqüente que alí deixou gravada, no dia 27 de abril de 1959, a pena sempre irriquieta e sempre ativa de Raul Rodrigues Gomes:

"Assino o ponto de minha última aula. Faço-o deixando aqui, na forma de um parecer e pensamento contra um dispositivo constitucional que me despede da Cátedra quando podia regê-la por mais dez anos. Como, porém, é lei, seja cumprida mediante protesto meu".

Senhores. Raul Gomes é isso mesmo: um mestre infatigável da energia e da operosidade. É um roteiro a seguir e um exemplo a imitar". 